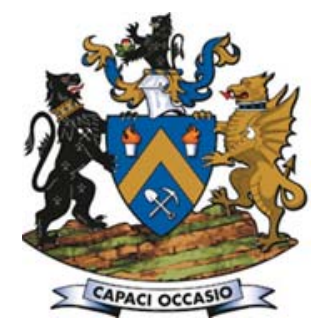

\title{
Investigation of Western Australia's rehabilitation fund as a fiscal policy solution for South African abandoned mines
}

\author{
by D. Klopper* and J-A. Wessels*
}

\section{Synopsis}

South Africa's mining legacy has resulted in a large number of abandoned mines which pose ongoing environmental threats. The regulatory framework makes no provision for cases of abandoned mines, nor does the legislation delegate due responsibility or have an approved strategic plan for their rehabilitation. A mixed methods approach was taken to investigate the challenges related to South African abandoned mine sites and to compare South Africa's legal provisions for abandoned mine site management with those of Western Australia, specifically the Mining Rehabilitation Fund (MRF) Act. Surveys and semi-structured interviews were conducted to ascertain industry attitudes towards the viability of Western Australia's fiscal policy solution for South Africa. Industry stakeholders are reluctant to accept responsibility for previous mine-owners' actions and the lax legislative controls under which mines operated in the past. It was found that the current implementation and enforcement of legislation in South Africa is lacking in some regards, but if all responsible parties work towards a common goal of funding the rehabilitation of abandoned mines the Western Australian fund may be a feasible fiscal policy solution for South Africa.

Keywords

abandoned mines, rehabilitation, fiscal policy solution, South Africa, Western Australia.
According to Swart (2003), a site is abandoned when the owners are liquidated or when the owners are traceable but do not necessarily have the capability or financial means to carry out sufficient post-closure rehabilitation. The sites are not classified as derelict and ownerless mines (D\&O), which bear legal ramifications as responsible persons are untraceable. The AGSA (2009, p. 1) of South Africa notes that the regulatory framework 'does not provide for cases of abandoned mines' nor does the legislation delegate due-responsibility or 'have an approved strategic or business plan' for their rehabilitation.

The Council for Geoscience (CGS) officially listed a total of 5906 abandoned sites in RSA as of May 2008 (AGSA, 2009, p. 6) of which the 'majority had closed down prior to 2002 when the Minerals and Petroleum Resources Development Act 28 of 2002 (MPRDA) (South Africa, 2002) came into effect.' According to the Auditor General (2009, p. 5) during the 2007/08 and 2008/09 financial years the DMR estimated the cost of the rehabilitation of these sites to be R30 billion. Of the 5906 abandoned mine sites in RSA, the CGS classified 1730 as high-risk sites which would cost an estimated R28.5 billion to rehabilitate. This amount excludes the cost of long-term acid mine drainage (AMD) treatment for affected sites and further operating costs such as for the stabilization of tailings, revegetation, or pumping of water to prevent shafts from flooding and decanting (AGSA, 2009, p.,5). The RSA Treasury does not have access to sufficient funds, justifying the need for a fiscal policy solution.

\footnotetext{
* School of Geo- and Spatial Science, Unit for Environmental Sciences and Management, NorthWest University, Potchefstroom, South Africa.

(c) The Southern African Institute of Mining and Metallurgy, 2017. ISSN 2225-6253. Paper received Jul. 2016; revised paper received Jan. 2017.
} 


\section{Investigation of Western Australia's rehabilitation fund as a fiscal policy solution}

According to Peck et al. (2005, p. vii) the negative impacts of mining practices could be adequately mitigated with the guidance of a stringent legislative framework and the implementation of 'sustainable policy-, capacity- and institutional- developments.' Western Australia, which faces similar challenges with funding for rehabilitation of abandoned mine sites, has passed the Mining Rehabilitation Fund Act 33 of 2012 (MRF) (Western Australia, 2012) to alleviate the financial burden on government. This study explores the opportunity of the MRF to provide a fiscal policy solution for the rehabilitation of South African abandoned mines and to instigate real and measurable action.

\section{Methodology}

The research methods included an in-depth qualitative literature review on existing bodies of knowledge (Grant and Booth, 2009), a comparative analysis between the legal provisions for abandoned mine sites management in RSA and WA, and semi-structured interviews with 25 stakeholders in the mining sector. Although the interviews were conducted before the National Environmental Management-Regulations (NEM-R) (South Africa, 2015) were introduced, the regulations do not impact the way legislation is implemented in South Africa.

The qualitative literature and interview data was coded and tabled based on 'interconnected categories of knowledge' (Creswell, 2013). Three quantitative questions in the survey measured the respondents' 'degrees of agreeability and the intensity of their feelings by means of Likert-type questions' (Bryman, 2012, p. 712) toward the various aspects of the viability of the MRF as a fiscal policy solution for South African abandoned mines. The comparative analysis aimed to enhance the understanding of the workings of the two legislative frameworks.

\section{The Western Australian MRF as a fiscal policy solution}

The South African legislative framework does not mention abandoned mines specifically but it is inferred from sections 28 and 24R(1) of the National Environmental Management Act 107 of 1998 (NEMA) (South Africa, 1998) and section 34(a) of the MPRDA (South Africa, 2008) that the mining right holder remains liable for their abandoned mines (which are a source of pollution) and the sustainable closure thereof until a closure certificate is issued by the Minister of Mineral Resources. Botham (2012, p. iv) is quoted as saying 'in South Africa no mine closure certificates have ever been issued under either the Minerals Act of 1991 or the MPRDA of 2002', possibly due to the difficulty in ensuring the longterm sustainability of rehabilitation and the prevention of environmental liabilities or risks in the future. The Department of Environmental Affairs (DEA) and the Department of Mineral Resources (DMR) do not claim responsibility for the sites and technically consider all holders of mining rights responsible for their abandoned sites.

Western Australia's abandoned mines total 11411 (Geological Survey of Western Australia, 2016), for which the rehabilitation costs are estimated to be between $\mathrm{A} \$ 4$ billion and A $\$ 6$ billion (Leybourne, 2014). As indicated by Morrison-Saunders and Pope (2013, p. 212), the sites pose a 'social, environmental and financial challenge for the government', and a financial burden on taxpayers. In hopes of addressing the issue, the MRF was implemented to encourage concurrent rehabilitation practices, prevent further abandonment of sites adding to the already burdensome legacy, and to generate funds for the rehabilitation of the legacy mines.

The MRF is a 'government-administered, pooled fund' (Western Australia, S5 of Act 33 of 2012), and according to section 8(1)-(2) of the MRF Act (Western Australia, 2012) the interest generated by the fund will be used to rehabilitate those sites which form part of the legacy of abandoned mines. According to section 9A of the MRF Act (Western Australia, 2012) 'tenement holders are not excused from carrying out mine closure and rehabilitation as stipulated in the approved mining plans and programmes'. The MRF will only provide funds for the rehabilitation of abandoned mining areas 'after every effort has been made to trace responsible parties and recover funds' (Western Australia, $2013 \mathrm{a}$, p. 2), and only in the event of the mine undergoing premature closure and being unable to complete closure as planned due to lack of financing will the capital held in the fund be accessed to assist in the rehabilitation of these abandoned sites. A Mining Rehabilitation Advisory Panel is established under the MRF Act (Western Australia, 2012) section 33, whose members function as advisors on matters relating to administration and implementation of the Act. The first rehabilitation efforts of the MRF were realized in 201516 when five sites were selected for rehabilitation to be managed by the Abandoned Mines Program (Western Australia, 2016a) and carried out according to the Abandoned Mines Policy (Western Australia, 2016b).

The MRF requires that all holders of mining authorizations in WA make an annually recalculated, nonrefundable contribution to the MRF of approximately $1 \%$ of the total estimated mine closure liability for each site (Western Australia, 2013a). This is based on, and proportionate to, the 'disturbance data and outstanding rehabilitation on the site' as required by section 12 of the MRF Act (Western Australia, 2012) and by the DMP (Western Australia, 2013a, p. 4). If mining impacts are concurrently managed and rehabilitated, the annual levy will decrease. The promulgation of the MRF Act was well received in the Western Australian mining industry and 95\% of tenement holders had submitted disturbance reports for 2013-14 and 98.8\% for 2015-16 (Western Australia, 2016c).

The WA MRF functions as a replacement for the performance bond system which quarantined funds (Western Australia, 2010, p. 4), and since the introduction of the MRF, more than Aus\$ billion in security bonds was returned to the mining sector to help free up funds for concurrent rehabilitation activities (Western Australia, 2016c, p. 1). In extreme cases, retirement bonds were not retired if the DMP CEO determined that a site poses a high risk of rehabilitation liability which would not be adequately covered by the payment of the annual levy. Regarding the financial incentives for WA mines, in a Norton Rose Fulbright (2013) article dated August 2013, it was noted that previously the main incentive for meeting rehabilitation obligations was the required performance bond. The annual levy as required by the MRF Act, which only requires $1 \%$ of total closure costs, 


\section{Investigation of Western Australia's rehabilitation fund as a fiscal policy solution}

may not be sufficient in encouraging exhaustive rehabilitation, considering a mine would have to operate for 100 years before the full rehabilitation costs would be reached, hence it may be a small price to pay with little incentive for environmental cleanup. Entirely doing away with the security bonds leaves room for underfunding if the end-of-life liabilities are underestimated and if concurrent rehabilitation activities are not wholly provided for. This again places the burden of responsibility on the government and taxpayers. Critics say that the implementation of the MRF came at a bad time when commodity prices were in a downward trend. Seventy-three mining projects suspended operations and four collapsed entirely shortly after having been returned their security bonds, resulting in underfunding of rehabilitation activities (Barrett, 2016; Masige, 2016).

Clark and Clark (2005, p. 68) mention the comparable role of governments around the world to 'enact and implement appropriate policy and legislation', thereby protecting themselves from major financial burdens and persisting environmental concerns. The new South African NEM-Regulations (South Africa, 2015) pertaining to the financial provision for prospecting, exploration, mining, or production operations encourage concurrent rehabilitation and make it a priority, changing the rehabilitation protocol as of 20 November 2015. Appendix 3 has introduced more stringent requirements for annual rehabilitation plans to be risk-monitored, measurable, compiled with the help of specialists, and auditable. It requires the reporting of shortcomings experienced during the year, ensuring continual growth through lessons learned. The RSA DEA requires financial provisioning for remediation and rehabilitation actives and decommissioning and closure, as stated in section 6 of the NEM-R (South Africa, 2015), in the form of bank guarantees, trust funds, and cash deposits, as per section 8(1) of NEM-R (South Africa, 2015).

Adopting a policy such as this in South Africa could address many of the financial challenges associated with abandoned mines. The success of the policy will be determined by how it is adapted to fit the unique requirements of South Africa and whether or not it can be implemented and enforced effectively.

\section{Results and analysis}

Categories of responses, identified from literature and interview data, identify the challenges related to abandonment of mine sites in South Africa, which are presented in Figure 1.

It may be deduced from literature and interviews that stakeholders in the industry believe that the relevant government departments, such as the DMR and DEA do not do everything in their legislative power to ensure that current mining practices do not add to the burden of abandoned mines. The responses indicate that enforcement of existing legislation may be lacking, past and present polluters are not held accountable, and little guidance is offered to mining companies with regard to what is expected of them according to best-practice standards. The guideline document of the DMR, which all mining companies in South Africa rely on to calculate the financial provisions necessary for closure, has not been updated since 2005 and there has been no other form of assistance afforded to mines in terms of guideline documents for the preparation of environmental management plans (EMPs) or programmes (EMPrs) or mine closure plans until the release of the NEM-Regulations (South Africa, 2015). This has resulted in underestimations of closure costs, thereby increasing the likelihood of mining sites being

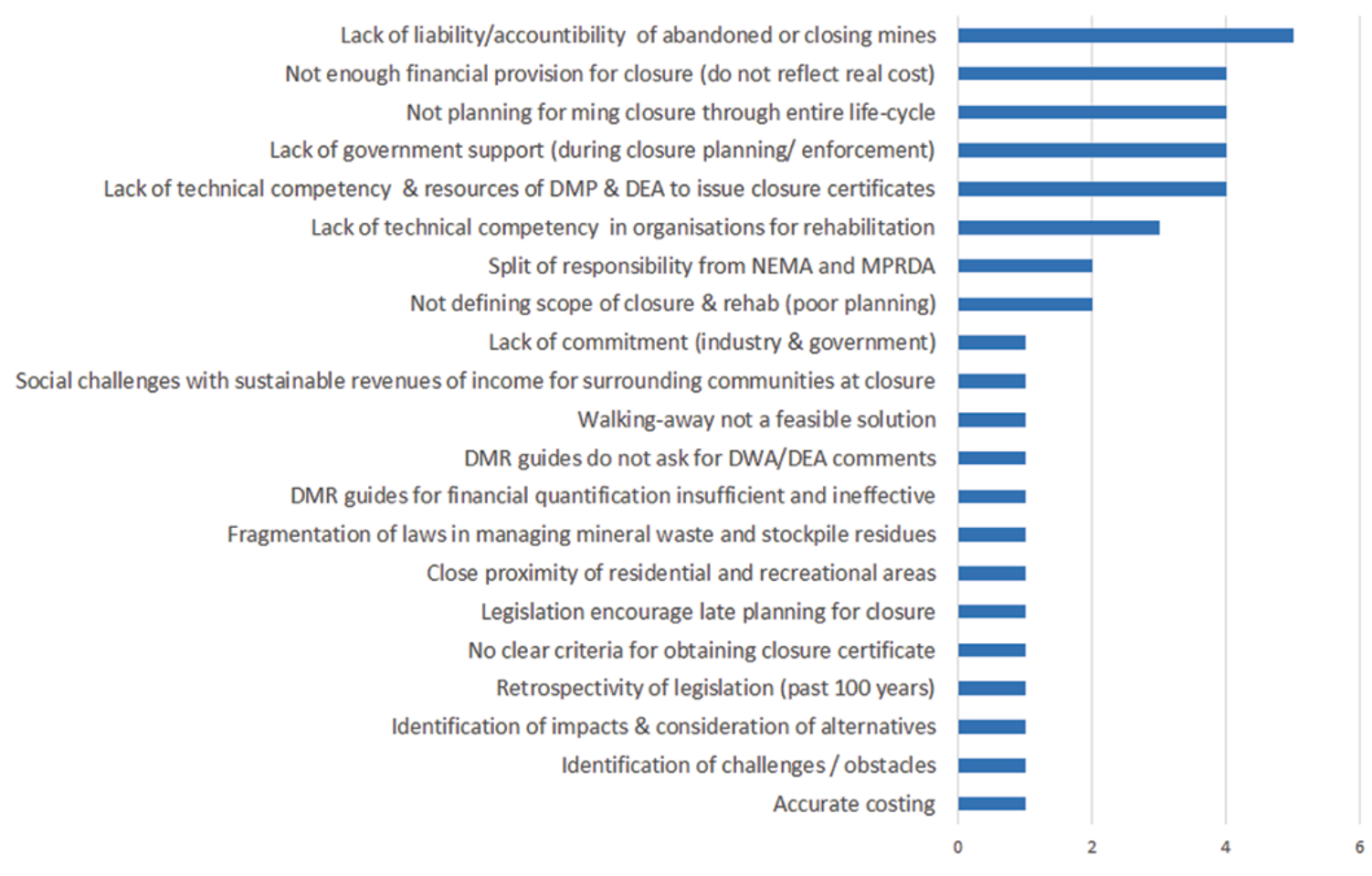

Figure 1-Frequency graph of survey responses on possible challenges related to mine site abandonment 


\section{Investigation of Western Australia's rehabilitation fund as a fiscal policy solution}

abandoned due to a lack of funding for rehabilitation, monitoring, and maintenance post-closure. There are no lessons learned across the industry as every company approaches mine closure planning individually, resulting in the same scenarios of inefficient practices and continued abandonment of sites.

The survey questions, as part of the interviews with stakeholders, shed light on the perceived viability of a fiscal policy solution such as the MRF to deal with the issues of abandoned sites and continued abandonment of sites. The first survey question asked whether the respondents thought the MRF would be beneficial for South Africa. The responses are concentrated in the 'partly agree' category, closely followed by 'agree' and 'strongly agree', indicating a great inclination to the agreeability of the benefits which such a policy could afford to South Africa. The second question measured the agreeability of the respondents to the viability of a solution such as the MRF for South Africa's abandoned mines. Once again the respondents' answers indicate that they agree as to the viability of the proposed fiscal policy solution. However, some respondents felt they 'strongly disagreed', indicative that although the policy may be highly beneficial, the viability thereof in the South African context is more uncertain. The last survey question asked agreeability to the statement that the South African government is capable of adopting and supporting (i.e. implementing) such a fund. The responses varied, with the majority of stakeholders 'strongly disagreeing' and the rest 'strongly' to 'partly agreeing'. The faith in the South African government's ability to implement legislation is uncertain and this will need to be addressed before any further legislation is drafted so that industry stakeholders may be assured that the implementation thereof will be fair and consistent.

The NEM-Regulations (South Africa, 2015) have attempted to address some of the identified problems. This entails more stringent monitoring requirements for the calculations of financial provisions, as seen in S14. Appendix 3 of the NEM-Regulations provides for the minimum content of an annual rehabilitation plan, providing better guidance concerning what is expected of mining operators. According to S2 (a) of Appendix 3, mines are required to 'review concurrent rehabilitation and remediation activities already implemented', and S2(d) 'identify and address shortcomings experienced in the preceding 12 months of rehabilitation', thereby ensuring that the most- and least-effective practices are identified. The threat of emergent liabilities has afforded an excuse for the DMR to not grant mine closure certificates. This is a major factor behind the abandonment of mines as mining companies do not make provision for indefinite monitoring and maintenance of their sites. Appendix 4 of the NEM-R (South Africa, 2015), which provides for the minimum content of a final rehabilitation, decommissioning, and mine closure plan, requires detailed and accurate financial planning, impact mitigation, and post-mining land use plans. These guidelines may just be what is necessary for mining companies to attain closure as they now have more details regarding the ministry's expectations of them.

Table I is a comprehensive summary of the comparative analysis of the two frameworks on the legal provisions specifically dealing with abandoned mine site management in the two countries.
The Environmental Protection Act (EPA) 76 of 1986 shows the intention to not only prevent further pollution, but also delegates responsibility to prevent, as far as possible, any environmental damage and mitigate the damage which cannot be prevented, as seen in section 16 which provides for the 'functions of authority' with respect to the 'prevention, control and abatement of pollution and environmental harm'. For cases of sudden and unexpected closure, as guided by sections 24 and 88 of the Mines Safety and Inspection Act 62 of 1994 (Western Australia, 1994), the closure process will be sped up, a decommissioning plan will need to be drafted, and the Mine Closure Plan needs to be reviewed within 3 months of abandonment (Western Australia, 2013). Up until the time of a closure certificate being issued, the mining operations remain the responsibility of the holder or other responsible appointed party, as directed by section $114 \mathrm{~B}$ of the Mining Act 107 of 1978.

Sections 28 and 24R(1) of NEMA (South Africa, 1998) and section 43(1) of the MPRDA (South Africa, 2002) support the polluter-pays principle and provide for retrospective action in terms of liability for the pollution and degradation of the environment. The DMR has developed the National Strategy for the Management of D\&O Mines (DMR, 2009) but a strategic plan is yet to be developed to deal with the rehabilitation of abandoned mines. As per section 46 of the MPRDA (South Africa, 2002) 'Parliament should set aside funds to employ a third party for the rehabilitation of a prematurely abandoned site where it is urgently needed to prevent environmental degradation'. These funds, according to section 46(1) are to be 'retrieved from the right holder'. Currently abandoned mines are not being factored into the parliamentary budget, as indicated by the Mineral Resources Minister (Wait, 2012).

Section 15 of the Mining Act Regulations (Western Australia, 1981) provide for 'expenditure conditions' and require that mining operators provide for a performance bond, according to section 126 , which serves as a form of financial security for closure rehabilitation, and section $60(1)$ of the Mining Act states 'the applicant for an exploration license shall lodge ... a security for compliance with the conditions to which the exploration license ... will ... be subject'. The MRF Act (Western Australia, 2012) has now replaced the bonds system as the mandated financial security and makes use of a government-administered 'pooled fund' (Western Australia, 2013a, p. 2), into which annual levies are paid. As the mines still operate under the Mining Act (Western Australia, 1978) they remain responsible for financing the rehabilitation of site according to the approved mine closure plan as per Western Australias Guidelines for Preparing Mine Closure Plans (DMP and EPA, 2011, p. 26). The purpose of the MRF Act (Western Australia, 2012), according to section 6 thereof, is 'to provide a source of funding for the rehabilitation of abandoned mine sites and other land affected by mining operations carried out in, on or under those sites'.

Section 8 of the NEM-Regulations (South Africa, 2015) provide for the use of a financial guarantee and trust fund system to ensure financial provision for mine closure. There is, however, no policy in place to rehabilitate abandoned mine sites and South Africa could benefit from the implementation of a fiscal policy solution such as that of Western Australia. 


\section{Investigation of Western Australia's rehabilitation fund as a fiscal policy solution}

\begin{tabular}{|c|c|c|c|c|c|}
\hline \multicolumn{6}{|c|}{ Table I } \\
\hline \multicolumn{6}{|c|}{ Summary of the comparative analysis between South Africa and Western Australia's applicable legislation } \\
\hline \multirow{2}{*}{\multicolumn{2}{|c|}{ Comparative categories }} & \multicolumn{2}{|r|}{ SOUTH AFRICA } & \multicolumn{2}{|r|}{ WESTERN AUSTRALIA } \\
\hline & & Source & \multirow{2}{*}{$\begin{array}{l}\text { Relevant extract(s) \& comments } \\
\qquad \text { S24(a),(b)(i-iii) }\end{array}$} & Source & Relevant extract(s) \& comments \\
\hline \multirow{3}{*}{ 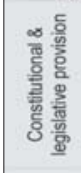 } & $\begin{array}{l}\text { Constitution on the } \\
\text { environment }\end{array}$ & \multirow[b]{2}{*}{ Constitution of RSA } & & \multirow{2}{*}{$\begin{array}{l}\text { Constitution of } \\
\text { WA \& } \\
\text { Commonwealth } \\
\text { Constitution }\end{array}$} & Neither Constitution specfically mentions the environment. \\
\hline & $\begin{array}{l}\text { Provides for national } \\
\text { legislation to protect } \\
\text { environment }\end{array}$ & & $\begin{array}{l}\text { S146(2)(vi), defines \& establishes sustainability principles \& the } \\
\text { DMR's constitutional mandate. }\end{array}$ & & $\begin{array}{l}\text { The Commonwealth of Australia makes legislative provision in the } \\
\text { forms of other Acts which deal specifically with the environment. }\end{array}$ \\
\hline & $\begin{array}{l}\text { Relevant environmental \& } \\
\text { mining legislation }\end{array}$ & & NEMA, NEM-R, MPRDA \& MPRD-R & & EPACt, EPBCA, MRF Act \& MA \\
\hline \multirow{6}{*}{ 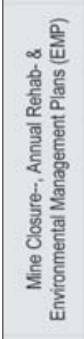 } & $\begin{array}{l}\text { Are Mine Closure } \\
\text { Plans/EMPs required? }\end{array}$ & MPRDA \& NEM-R & $\begin{array}{l}\text { EMP is required which aids in guiding mines in effective closure. } \\
\text { Final Mine Closure Plans not required until mine closure is } \\
\text { imminent, but kept up to date with annual rehab plan. }\end{array}$ & \multirow{3}{*}{$\begin{array}{l}\text { The Guidelines for } \\
\text { the Preparation of } \\
\text { Mine Closure } \\
\text { Plans \& MA }\end{array}$} & $\begin{array}{l}\text { Mine Closure Plan to be submitted as part of the Mining Proposal } \\
\text { (S700 of the MA amendments). }\end{array}$ \\
\hline & $\begin{array}{l}\text { When to be made } \\
\text { avalable? }\end{array}$ & $\begin{array}{l}\text { NEMA, NEM-R \& } \\
\text { MPRDA }\end{array}$ & EMP required before the mining permit is issued. & & $\begin{array}{l}\text { Internationally accepted best practice: plan for closure before } \\
\text { commencement of any activities. }\end{array}$ \\
\hline & $\begin{array}{l}\text { How often should they be } \\
\text { updated? }\end{array}$ & MPRD-R \& NEM-R & S55; as stipulated in the EMP otherwise annually. & & $\begin{array}{l}\text { Reviewed throughout life of mine \& submitted to DMP every three } \\
\text { years for approval. }\end{array}$ \\
\hline & \multirow{3}{*}{$\begin{array}{l}\text { Are there government } \\
\text { developed guidelines for } \\
\text { their formulation? }\end{array}$} & $\begin{array}{l}\text { MPRD-R } \\
\text { NEMA \& MPRDA \& } \\
\text { MPRD-R }\end{array}$ & $\begin{array}{l}\text { S51\& S52 provide a basic idea of the contents of an EMP. } \\
\text { Provide for mine closure principles (MRPD-R, S56) \& provide } \\
\text { generic descriptions for contents of closure plan (MPRD-R, S62). }\end{array}$ & \multirow{3}{*}{$\begin{array}{l}\text { The Guidelines for } \\
\text { the Preparation of } \\
\text { Mine Closure } \\
\text { Plans (DMR \& } \\
\text { EPAuth, 2011) }\end{array}$} & Suggest the structure and content of the Mine Closure Plan and \\
\hline & & $\begin{array}{l}\text { Info. Series } 12 \text { (DEAT. } \\
\text { 2004) }\end{array}$ & $\begin{array}{l}\text { Supportive text (clearly stipulated that this is not a guideline } \\
\text { document) to support with the formulation of EMPs. }\end{array}$ & & $\begin{array}{l}\text { provide all the necessary legal and best practice information } \\
\text { regarding Mine Closure Plans. }\end{array}$ \\
\hline & & NEM-R & Appendices 384 & & \\
\hline \multirow{5}{*}{ 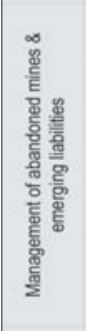 } & \multirow{4}{*}{$\begin{array}{l}\text { Responsible parties post- } \\
\text { closure }\end{array}$} & \multirow[b]{2}{*}{ NEMA \& MPRDA } & \multirow{2}{*}{$\begin{array}{c}\text { NEMA S24R(1), S28 \& MPRDA S43(1) supports "polluter pays } \\
\text { principle" \& holds polluters responsible for degradation caused } \\
\text { before promulgation of NEMA \& indirect pollution as a result of } \\
\text { polluting activities. Polluters remain responsible even when ceased } \\
\text { to exist. }\end{array}$} & EPACt & $\begin{array}{l}\text { S16: Appointed authorities responsible for encouraging protection of } \\
\text { the environment. }\end{array}$ \\
\hline & & & & \multirow[t]{2}{*}{ MRF Act } & \multirow{2}{*}{$\begin{array}{l}\text { S9A: person responsible for site \& rehab thereof at time of it being } \\
\text { declared abandoned, is liable to pay a cost into MRF as debt due to } \\
\text { state. Once established that liable person is unable to provide for } \\
\text { rehab, MRF comes into effect \& rehabilitates. }\end{array}$} \\
\hline & & & $\begin{array}{l}\text { MPRDA S 46(1): if holder ceased to exist or is liquidated \& rehab } \\
\text { is required. Mnister must "take necessary measures to prevent }\end{array}$ & & \\
\hline & & NEMA \& MPRDA & $\begin{array}{c}\text { further pollution or degradation", after which Minister may recover } \\
\text { costs of remediation from responsible party (previous holder of } \\
\text { mining right) }\end{array}$ & MA & $\begin{array}{l}\text { S114B: continuation of liability after expiry, surrender or forfeiture of } \\
\text { mining tenement \& don't excuse previous holders from closure } \\
\text { liabilities }\end{array}$ \\
\hline & $\begin{array}{l}\text { Legislative provisions for } \\
\text { abandoned mines }\end{array}$ & & $\begin{array}{l}\text { There is no legal document in place which specifically deals with } \\
\text { abandoned mines. The legislation does not delegate due- } \\
\text { responsibility or have an approved strategic or business plan for } \\
\text { the rehab of sites. }\end{array}$ & $\begin{array}{l}\text { MSI Act \& MRF } \\
\text { Act }\end{array}$ & $\begin{array}{l}\text { MSI Act S42(1)(a): notify DMP before abandonment \& cessation of } \\
\text { activities. S88: plans for abandonment or suspension. Mine Closure } \\
\text { Plan: updated within } 3 \text { months to include decommissioning- \& care \& } \\
\text { maintenance plans. MRF Act S8: funding rehab of abandoned mines. }\end{array}$ \\
\hline \multirow{2}{*}{ 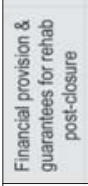 } & $\begin{array}{l}\text { Financial provisions for } \\
\text { mine closure }\end{array}$ & $\begin{array}{l}\text { MPRDA, MPRD-R \& } \\
\text { NEM-R (entire } \\
\text { document) }\end{array}$ & $\begin{array}{l}\text { S23(1), S10(k) \& S53 (MPRD-R) Financial provision must be } \\
\text { provided before EMP may be approved or environmental } \\
\text { authorisation awarded. Financial guarantees are required. }\end{array}$ & MRF ACt & $\begin{array}{l}\text { Mines are responsible for providing finances for rehab in any form } \\
\text { they deem fit. The mandatory financial provision is made by paying } \\
\text { annual levies into the MRF (S11). }\end{array}$ \\
\hline & $\begin{array}{l}\text { Calculations of financial } \\
\text { provisions }\end{array}$ & $\begin{array}{l}\text { Quantum guideline } \\
\text { (DME, 2005) \& NEM-R }\end{array}$ & $\begin{array}{l}\text { Administrated by the DMR - quantum guideline is principle } \\
\text { guideline document for calculating closure costing. Last updated in } \\
\text { 2005. NEM-R S11(2) requires annual updating of financial } \\
\text { provisions. }\end{array}$ & $\begin{array}{l}\text { MRF Act \& } \\
\text { Regulations }\end{array}$ & $\begin{array}{l}\text { MRF Regulations provide comprehensive guide for calculations of the } \\
\text { annual levy payable. The financial provisions for rehab of sites may } \\
\text { be provided in any form \& may be calculated based on previous } \\
\text { guidelines (DMR \& EPAuth) which are no longer obligatory. }\end{array}$ \\
\hline \multicolumn{6}{|c|}{ Terms and abbreviations used in Table I } \\
\hline \multirow{3}{*}{\multicolumn{2}{|c|}{$\begin{array}{l}\text { Commonwealth Constitution } \\
\text { Constitution of RSA } \\
\text { Constitution of WA }\end{array}$}} & \\
\hline & & \multicolumn{4}{|c|}{ Constitution of the Republic of South Africa Act 108 of 1996} \\
\hline & & \multicolumn{4}{|c|}{ Western Australia's Constitution Act 23 of 1889} \\
\hline \multicolumn{2}{|c|}{ EPAct } & \multicolumn{4}{|c|}{ Environmental Protection Act 87 of 1986} \\
\hline \multicolumn{2}{|c|}{ EPBCA } & Environmental Protec & tion, Biodiversity Conservation Act 91 of 1999 & & \\
\hline Quant & um guideline & Guideline document $f$ & or the evaluation of the quantum of closure-related fina & provision $\mathrm{p}$ & d by a mine \\
\hline MA & & The Mining Act 107 of & 1978 & & \\
\hline MPRD & & Minerals and Petroleu & m Resources Development Act 28 of 2002 & & \\
\hline MPRD & & MPRD Regulations of & 2004 & & \\
\hline & & Mining Rehabilitation & Fund Act 33 of 2012 & & \\
\hline & & Mines Safety and Insp & ection Act 62 of 1994 & & \\
\hline NEMA & & National Environment & al Management Act 107 of 1998 & & \\
\hline NEM- $-\mathrm{F}$ & & National Environment & al Management Regulations of 2015, GG 39425 & & \\
\hline
\end{tabular}

\section{Discussion}

The continued abandonment of mine sites in South Africa points to some crucial shortcomings in the implementation of, and enforcement of, existing legislation. The lack of competency, both in the mining sector and government, with regard to the compilation of Mine Closure Plans and EMPs, continues to supplement the abandonment of sites as the quality of documents varies greatly and government simply does not have adequately trained personnel or policy guidelines to assess the quality of documents produced or to enforce existing laws. This perpetuates the cycle of inefficient closure planning and tolerates the bare minimum with regard to efforts made to comply with legislative requirements. Before November 2015 mining companies had to rely on the out-of-date Guideline document for the evaluation of the quantum of closure related financial provision (South Africa, 2005), which resulted in serious shortfalls regarding financial provision for closure.
Government's legislative mandate is to provide guidance for the formulation of procedures and assess these procedures to ensure compliance. It is hoped that the new NEM-Regulations (South Africa, 2015), which provide more stringent guidance on what is expected regarding financial provision for mine closure, will address this problem of underestimations and prevent further abandonment of mines. This will, however, only make an impact if the legislation is properly implemented. An investigation into the implementation and impacts of the new regulations may present a further research opportunity.

The comparison of the legislative frameworks of South Africa and Western Australia highlighted some key areas of shortcomings which potentially lead to the abandonment and ongoing degradation of sites. Based on the literature review it is evident that South Africa, unlike Western Australia, has no specific policy in place to deal with the legacy of abandoned mines and does not have the financial means to undertake 


\section{Investigation of Western Australia's rehabilitation fund as a fiscal policy solution}

such a mammoth task. Secondly, the existing legislation that aims to prevent further abandonment of sites is not properly implemented. The assessment of the interview and literature data revealed that government does not draft up-to-date and stringent guidelines for mines and that mines then do not carry out proper assessment and monitoring procedures. Best-practice industry guidelines could help alleviate some of the strain on the industry and the NEM-Regulations (South Africa, 2015) have started to address this. Mine closure plans do not provide for life-long monitoring of mines where operations have ceased and oftentimes don't provide finances for the ongoing monitoring and maintenance of the site. By permitting mining activities, the government also enters into an agreement that it will take over responsibility for the site once rehabilitation is completed according to the mine closure plan and a closure certificate is issued. Based on the responses, it is evident that the South African government does not easily accept responsiblilty for the implications related to mining.

Once mining operations have ceased, the site still needs to be monitored and maintained and proactive measures need to be taken to maintain the natural ecosystems in good health for the benefit of the entire country. The survey responses indicate that there is a displacement of liabilities and lack of accountability, which leads to the question of who is to take responsibility for these sites as they continue to degrade the environment and infringe on South Africans' constitutional rights.

From comparative analysis of the legislative frameworks and the literature review, it is evident that policies, regulations, guidelines, and legislative documents need to be aligned with one another in order to support unified goals and provide a clear indication of what is expected of mining plans and development projects. When a legal framework is not properly implemented and up-to-date, all-encompassing legislation cannot be drafted, irresponsible mining practices ensue, and rehabilitation is not done properly, giving rise to a state of constant environmental deterioration.

Interview responses indicated that stakeholders in the mining industry regard it as unjust to hold current mining operators responsible for the wrongdoings of past miners and the ineffective legislation which permitted the neglect of the environment. The crux, however, lies in the mining activity itself, which if not approached correctly, is wholly unsustainable. In essence, if mining operators draw their profits from the environment, they should be willing to pay a percentage of their income to assist in dealing with the persistent negative impacts of the mining industry's activities as a whole. As can be seen from the Western Australian example, it is possible to obtain the support of the industry, as long as the enforcing party, in this case the government or a third party, does its part in ensuring that it provides proper guidance and fair enforcement and implementation of the legislation, free of corrupt activities. A vehicle such as the Western Australian fund may thus be a feasible fiscal policy solution for South African abandoned mines, when and if all parties involved give their support to the cause.

\section{References}

Auditor-General of South Africa (AGSA) 2009. Report of the Auditor-General to Parliament on a performance audit of the rehabilitation of abandoned mines at the Department of Minerals and Energy, South Africa. Pretoria. http://cer.org.za/wp-content/uploads/2011/10/AG_Report_on_ abandoned_mines-Oct-2009.pdf [accessed 12 April 2014].

Australian Commonwealth. 1900. Commonwealth of Australia Constitution Act 1900. Parliament of the United Kingdom, Westminster.

BARRETT, J. 2016. Australian miners leave clean-up bill after taking the cash, Reuters, 1 August 2016. http://www.reuters.com/article/us-australiamining-environment-idUSKCN10D094 [accessed 18 January 2017].

Вотнам, N.D. 2012. A critical analysis of mine closure process as followed by the De Beers Oaks Diamond Mine, Limpopo, South Africa. MA thesis, University of Johannesburg.

Bryman, A. 2012. Social Research Methods. 4th edn. Oxford University Press, New York.

CLARK, A.L. and CLARK, J.C. 2005. An international overview of legal frameworks for mine closure. Environmental Law Alliance Worldwide. http://www.elaw.org/node/3715 [accessed 9 June 2014].

Creswell, J.W. 2013. Qualitative Inquiry and Research Design: Choosing Among Five Approaches. 5th edn. Sage, Thousand Oaks, CA.

Department of Mines and Petroleum and Environmental Protection Authority (DMP and EPA). 2011. Guidelines for preparing mine closure plans June 2011. Government of Western Australia, Perth. http://edit.epa.wa.gov.au/EPADocLib/Guidelines-for-preparingmineclosure-plans-210611.pdf [accessed 25 August 2014].

Department of Mineral Resources (DMR). 2009. The national strategy for the management of derelict and ownerless mines in South Africa. Government Printer, Pretoria.

Geological Survey of Western Australia (GSWA). 2016. Mines and mineral deposits (MINEDEX). http://www.dmp.wa.gov.au/Mines-and-mineraldeposits-1502.aspx [accessed 17 January 2017].

GRANT, M.J. and BоотH, A. 2009. A typology of literature reviews: an analysis of 14 review types and associated methodologies. Health information and Libraries Journal, vol. 26, no.2. pp.91-108.

Leybourne, M.L. 2014. Ensuring rehabilitation into the future - The Western Australian Mining Rehabilitation Fund. Proceedings of the Life-of-Mine Conference 2014, Brisbane, Queensland, 16 July 2014. Australasian Institute of Mining and Metallurgy, Melbourne. pp. 441-448.

MASIGE, S. 2016. Failed mine rehabilitation fees could have taxpayers footing the bill. Australian Mining, 3 August 2016.

https://www.australianmining.com.au/news/failed-mine-rehabilitationfees-taxpayers-footing-bill/ [accessed 18 January 2017].

MENÉnDEZ, J.M.A. 2005. Harmonising policy and technology: environmental regulation of mine waters in the United Kingdom and European Union. PhD thesis, University of Newcastle.

Morrison-SAunders, A. and Pope, J. 2013. Mine closure planning and social responsibility in Western Australia: Recent policy innovations. SR Mining 2013, Proceedings of the 2nd International Conference on Social Responsibility in Mining, Santiago, Chile, 5-8 November 2013. Centre for Social Responsibility in Mining, Sustainable Minerals Institute, University of Queensland. Chapter 3.

Norton Rose Fulbright. 2013. Mine site closure in WA and the new Rehabilitation Fund. http://www.nortonrosefulbright.com/ knowledge/publications/102325/mine-site-closure-in-wa-and-the-newrehabilitation-fund [accessed 24 Nov. 2016].

Peck, P., Balkau, F., Bogdanovic, J., Sevaldsen, P., Skaalvik, J. F., Simonett, O., Thorsen, T.A., Kadyrzhanova, I., and Svedberg, P. 2005. Mining for Closure; policies and guidelines for sustainable mining practice and closure of mines. Environment and Security (EnvSec) Initiative Project, UNEP, UNDP, OSCE, and NATO. https://www.commdev.org/miningclosure-policies-and-guidelines-sustainable-mining-practice-and-closuremines [accessed 21 May 2014].

South AFricA. 1996. Constitution of the Republic of South Africa Act 108 of 1996, Government Gazette, vol. 378, no. 17678. 8 May 1996.

SOUTH AFRICA. 1998. Department of Environmental Affairs (DEA). National Environmental Management Act 107 of 1998, Government Gazette, vol. 19519, no.1540. 27 November 1998.

SOUTH AFRICA. 2002. Department of Mineral Resources (DMR). Mineral and Petroleum Resources Development Act 28 of 2002. Government Gazette, vol. 23922, no. 1273. 10 October 2002, as amended. Mineral and Petroleum Resources Amendment Act 49 of 2008, Government Gazette, vol. 526, no. 32151, 21 Apr. 2009, as amended.

SOUTH AFRICA. 2004. Department of Mineral Resources (DMR). Mineral and Petroleum Resources Development Regulations (MPRD-R), No. 527 of 2004. Government Gazette, 10 October 2002. 


\section{Investigation of Western Australia's rehabilitation fund as a fiscal policy solution}

South AFriCA. Department of Minerals and Energy (DME). 2005. Guideline document for the evaluation of the quantum of closure-related financial provision provided by a mine. Government Printer, Pretoria.

South Africa. Department of Environmental Affairs (DEA). 2015. National Environmental Management Regulations: Regulations pertaining to the financial provision for prospecting, exploration, mining or production operations, Government Gazette, vol. 39425, no. 1147, 20 November 2015.

SwART, E. 2003. The South African legislative framework for mine closure. Journal of the South African Institute of Mining and Metallurgy, vol. 103, no. 8. pp.469-492.

United Nations Environmental Programme (UNEP). 2000. Mining and sustainable development II: Challenges and perspectives. United Nations Environment Programme Division of Technology, Industry and Economics, Paris, France.

United Nations Environmental Programme - Finance Initiative (UNEP-FI). 2012. Chief Liquidity Series, Issue 3: Extractives Sector. Geneva, Switzerland: UNEP-FI. http://www.unepfi.org/work_streams/water/liquidity [accessed 19 June 2014].

WAIT, M. 2012. DMR rehabilitates derelict and ownerless mines, not abandoned sites. Mining Weekly, 17 September http://www.miningweekly.com/article/dmr-rehabilitates-derelict-andownerless-mines-not-abandoned-sites-2012-09-17 [accessed 14 May 2014].

Western Australia. 1889. Constitution Act 23 of 1889. State Law Publisher, Perth.

Western Australia. 1978. Mining Act 107 of 1978. State Law Publisher, Perth. Western Australia. 1981. Mining Regulations of 1981. State Law Publisher, Perth.
Western Australia.1986. Environmental Protection Act 87 of 1986. State Law Publisher, Perth.

Western Australia. 1994. Mines Safety and Inspection Act 62 of 1994. State Law Publisher, Perth.

WeStern Australia. 1999. Environment Protection and Biodiversity Conservation Act 91 of 1999. State Law Publisher, Perth.

Western Australia. Department of Mines and Petroleum (DMP). 2010. Policy Options for Mining Securities in Western Australia: Preliminary Discussion Paper. Government of Western Australia; DMP, and, EPA, Perth. http://www.dmp.wa.gov.au/documents/100957_Policy_Options.pdf [accessed 10 May 2014].

Western Australia. 2012. Mining Rehabilitation Fund (MRF) Act 33 of 2012.

Western Australia. Department of Mines and Petroleum (DMP). 2013a. Mining Rehabilitation Fund Guidance. Perth. http://www.dmp.wa.gov.au/ Documents/Environment/ENV-MEB-382.pdf [accessed 18 January 2017].

Western Australia. 2013b. Mining Rehabilitation Fund Regulations (MRF-R) of 2013. Government Gazette, vol. 2423, no. 95. 21 June 2013.

Western Australia. Department of Mines and Petroleum (DMP). $2016 \mathrm{a}$. Abandoned mine program. Government of Western Australia, DMP. http://www.dmp.wa.gov.au/Environment/Abandoned-mines-projects18193.aspx [accessed 17 January 2017].

WeSTERn Australia. Department of Mines and Petroleum (DMP). 2016b. Abandoned mines policy. Perth: Government of Western Australia, DMP. http://www.dmp.wa.gov.au/Documents/Environment/ENV-MEB-201.pdf [accessed 17 January 2017].

WeStern Australia. Department of Mines and Petroleum (DMP). 2016c. Mining rehabilitation fund: yearly report 2016. Government of Western Australia, DMP, Perth. 